\title{
İlköğretim Din Kültürü ve Ahlak Bilgisi Öğretim Programının Eleştirel Düşünme Becerileri Açısından İncelenmesi ${ }^{1}$
}

\author{
DOI: 10.26466/opus.572254 \\ * \\ Eyyup Serkan Öncel*
}
* Öğr. Gör. Osmaniye Korkut Ata Üniversitesi, Yabancı Diller Yüksekokulu / Osmaniye / Türkiye E-Posta: esoncel@osmaniye.edu.tr ORCID:0000-0002-5337-5020

\section{Öz}

Bu çalışmanın amacı 2010 yılında uygulamaya konulan İlköğretim Din Kültürü ve Ahlak Bilgisi dersi öğretim programının eleştirel düşünme açısından incelemek ve değerlendirmektir. Günümüzde bilgi çeşitliliği ve miktarının çokluğu düşünmeyi ve özellikle de eleştirel dü̈sünme becerilerini ön plana çıkarmıştır. Bu çalışmada ilk olarak eleştirel düşünmenin farklı tanımları yapılarak önemi üzerinde durulmuştur. Daha sonra İlköğretim Din Kültürü ve Ahlak Bilgisi dersi (4-8 sinıflar) öğretim programında yer alan giriş, programın vizyonu, programın uygulanmasına ilişkin ilke ve açıklamalar, programın temel yaklaşımı, programın özellikleri ve geliştirilmesinde temel alınan ilkeler, programın yapısı, öğrenme-öğretme süreçleri ve öğretmenin rolü, vb. bölümlere eleştirel düşünmenin ne kadar yansıdığı incelenmiş ve tespit edilmiştir. Tespitler ve incelemeler yapılırken yurt içinde ve yurt dışında yer alan tezler, makaleler, kitaplar ve konu ile igili yapılmıs çalışmalardan yararlanılmıştır. Eleştirel düşünmenin Türkiye'deki İlköğretim Din Kültürü̈ ve Ahlak Bilgisi öğretim programına yansımasını incelemek için doküman incelemesi yöntemi kullanılmıştır. Sonuçta, eleştirel düşünme becerilerinin DKAB programın her safhasına yayıldığı, programda önemli bir yer teşkil ettiği tespit edilmiştir.

Anahtar Kelimeler: Din Eğitimi, Eleştirel düşünme, Eğitim program, Din kültürü ve ahlak bilgisi

\footnotetext{
${ }^{1}$ Bu çalışma, Atatürk Üniversitesi Eğitim Bilimleri Enstitüsünde yürütülmekte olan Din Eğitiminde Eleşti rel Düşünme isimli doktora tezinden üretilmiştir
} 


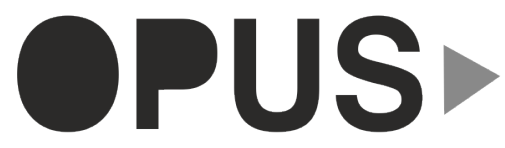

Uluslararası Toplum Araştırmaları Dergisi International Journal of Society Researches
E-ISSN : 2528-9535

YIl Year: 9

Cilt Volume: 11

Sayı Issue : 18

Haziran June 2019

Makalenin Gelis Tarihi Received Date:30/05/2019 Makalenin Kabul Tarihi Accepted Date: 23/06/2019

\title{
An Investigation of the Curriculum of Religious Culture and Morality in terms of Critical Thinking Skills
}

\begin{abstract}
The aim of this study is to analyse and evaluate the curriculum of religious culture and ethics which was put into practice in 2010 in primary schools in terms of critical thinking. Nowadays, the diversity of information and the amount of information has emphasized thinking and especially critical thinking skills. First, critical thinking has been emphasized by making different definitions in this study. Afterwards, the introduction, the vision of the program, the principles and explanations related to the implementation of the program, the basic approach of the program, the principles that are basic for the development of the program, structure of the program, learning-teaching processes and the role of the teacher were analysed in terms of critical thinking. As a result, it has been seen that critical thinking skills are spread to every stage of the program and it is an important place in the program. Theses, articles, books and studies related to the subject in Turkey and abroad were used in making the determinations and examinations. Document analysis method was used to examine the reflection of critical teaching skills on primary education religious culture and morality curriculum in Turkey. As a result, it has been determined that critical thinking skills spread to every stage of the program and constitute an important place in the program.
\end{abstract}

Keywords: Religious Education, Critical thinking, Curriculum, Religious culture and morality 


\section{Giriş}

21. yüzyıl insanı, hızla değişen ve gelişen dünya üzerine ayak uydurabilmesi için farklı donanım ve becerilere sahip olma durumundadır. Günümüz dünyasında birey ve toplumların yaşadıkları problemlerin çoğunun çözümü, sahip oldukları ve uyguladıkları düşünme becerileriyle ilgilidir. Bu düşünme becerileri gün geçtikçe daha da önem kazanmaktadır. Düşünme, kişiyi iç veya dış faktörler açısından rahatsız eden, kişinin fiziksel ve psikolojik balansını bozan faktörlerin kaybolması için yapılan bilinçli zihinsel davranışların bütünüdür (Kazanc1, 1989, s.2). Doğası gereği insan, günlük yaşam gereksinimlerini sürdürmek, yaşadığ çevreyi düzenlemek, amaçlarına ulaşabilmek, isabetli kararlar verip seçimler yapabilmek için daima düşünmek zorundadır.

Çağımızda bireylerin kendi düşünme süreçlerinin bilincinde, eleştirel düşünen, sorgulayan, analiz ve sentez yeteneğine sahip, yaratıcı ve bilimsel düşünebilen, problemler karşısında değişik bakış açıları geliştirebilen niteliklere sahip olmaları toplumsal yaşantıda aranan bir durum haline gelmiştir. Bireylerin düşünme şekillerinin keşfedilmesi ve düşünmenin öğretilebilmesi fenomeninin yaygınlı hale gelmesiyle bir düşünme türü olan "eleştirel düşünme" gündeme gelmiştir. Eleştirel kelimesi yargıda bulunma, değerlendirme, ayırt etme manalarını içeren Yunanca "kritikos" kelimesinden ortaya çıkmış, Latince'ye ise "critius" şeklinde geçiş yapmış ve bu şekilde başka dillere de geçmiştir. Eleştirel düşünme genel anlamda olayları ya da şeyleri iyi veya kötü yönleriyle değerlendirme anlamına gelmektedir (Kaya 1997, s.8). Eleştirel düşünme safhasında insanlar artık düşündükleri şeylerin iyi ya da kötü yönlerini değerlendirip bir yargiya varırlar.

Günümüzde eğitim, psikoloji ve felsefe gibi bilim alanları eleştirel düşünmeyi araştırma konusu yapmaktadır. Felsefi yaklaşım iyi düşünme ile ilgili normlar, insan düşüncesi ve objektif, gerçekçi bir dünya düşüncesine göre ihtiyaç olan zihinsel yetenekler üzerinde yoğunlaşırken, psikolojik yaklaşımlar düşünce ve düşünmeye odaklanan deneysel çalışmalar, kompleks düşüncelerin öğrenilmesindeki kişisel farklılıklar ve eleştirel düşünmeyi ilgilendiren problem çözme konsepti, eğitim ise düşünme becerilerinin nasıl öğretilebileceğiyle ilgilenmektedir (Kurnaz, 2013, s.10). Bu yüzden, adı geçen bu bilim dalları eleştirel düşünmeyle 
ilgili kendi tanımlarını yaptıklarından, literatürde eleştirel düşünmeyle ilgili farklı tanımlar ortaya çıkmaktadır. Bu tanımlardan bazıları aşağıda verilmektedir:

Chance (1986, s.236) eleştirel düşünmeyi; "olguları analiz etme, düşünce üretme ve onu örgütleme, görüşleri savunma, karşılaştırmalar yapma, çıkarımlarda bulunma, tartışmaları değerlendirme ve problem çözme yeteneği" olarak açıklamaktadır. Walters'a (1984, s.236) göre eleştirel düşünme okuma, yazma ve tartışmada meydana gelen kararsızlıkları tespit etme, beyanat, inceleme ve cevap verme aşamalarında öğrencilere kolaylık sağlayan problem çözücü bir süreçtir. Mckee (1988, s.444) eleştirel düşünme hakkında, sorgulamanın ve uslamlamanın dirik bir süreci, bilginin pasif malumatına rağmen işlek bir şekilde bilgiyi incelemek ve anlamları, eylemleri, fiilleri ve inanışları soruşturmak ve "yapılabilmiş olan ile henüz yapılabilecek olanı" düşünmektir şeklinde bilgi vermektedir. Cüceloğlu (1995, s.255-256) eleştirel düşünmeyi kendi düşünme sürecimizin farkında olarak, aynı zamanda da başkalarının düşünme süreçlerini de göz önünde bulundurarak, öğrendiklerimizi uygulayıp etrafımızdaki olayları anlayabilmemizi sağlayan aktif ve bilinçli bir zihinsel süreçtir şeklinde açılamaktadır.

Eleştirel düşünme hakkında yukarıda verilen çeşitli yaklaşım ve tanımlar değerlendirildiğinde ortak noktalar elde edilebilir. İlk olarak eleştirel düşünme; strateji, bilgi, tutum ve becerileri kapsayan bütüncül ve karmaşık bir düşünme sürecidir. Genel olarak, eleştirel düşünme gerçeği tarafsız olarak algılama sürecidir. Fakat gerçek bizim için göründüğünden daha farklı olabilir. Eleştirel düşünme bunu niçin tüm olumlu ve olumsuz, bize görünen ve görünmeyen yönleriyle gerçeği araştırıp ortaya koyma şeklidir. Eleştirel düşünmedeki akıl yürütme süreci bilgiye dayalıdır. Ancak burada kritik bir bilgilenme süreci mevcuttur. Bu basamakta bilgi kaynaklarının sorgulanıp, önyargıların ve sayıltıların tespit edilmesi gerekir. Nasıl ve niçin düşündüğünün farkında olan eleştirel düşünür hem kendi düşünme süreçlerinin hem de diğerlerin düşünme süreçlerinin farkındadır (Doğanay ve Ünal, 2006, s.222).

Paul, Binker, Jensen ve Krelau (1990, s.56-102) eleştirel düşünme stratejilerini "duyuşsal stratejiler", "bilişsel stratejiler-makro yetenekler" ve "bilişsel stratejiler-mikro beceriler" şeklinde üç ana grupta toplamışlardır. Bu stratejiler birbirinden bağımsızdır. "Duyuşsal stratejiler" 
bağımsız düşünme, ben merkezli ya da toplum merkezli iç görüler geliştirme, tarafsız düşünmeyi harekete geçirme, duygu ve düşünce arasındaki ilişkiyi anlama, zihinsel alçak gönüllüğü ve yargıyı geciktirmeyi geliştirme, zihinsel cesareti geliştirme, zihinsel iyi niyeti ve dürüstlüğü geliştirme, zihinsel azmi geliştirme, düşünme becerisine güven duymayı geliştirme becerilerini içermektedir.

"Bilişsel stratejiler" (makro yetenekler) genellemeleri arılaştırma ve aşırı basitleştirmekten kaçınma, benzer durumların karşılaştırma, bireyin bakış açısını geliştirme, sorunları, sonuçları ya da inançları açıklığa kavuşturma, Kelimeleri ya da söz öbeklerini açık hale getirme ve analiz etme, değerlendirme için ölçüt geliştirme, bilgi kaynaklarının güvenirliğini değerlendirme, derinlemesine sorgulama, savları, yorumları, inançları ya da kuramları analiz etme ya da değerlendirme, çözümler üretme ya da değerlendirme, eylemleri ya da politikaları analiz etme ya da değerlendirme, eleştirel okuma, eleştirel dinleme, disiplinler arası ilişki kurma, Sokratik tartışmayı uygulama, bakış açılarını, yorumları veya kuramları karşılaştırma, bakış açılarını, yorumları veya kurmaları değerlendirme becerilerini kapsamaktadır.

"Bilişsel stratejiler" (mikro beceriler) ise gerçek uygulama ile idealleri karşılaştırma ve birbirinden ayırt etme, düşünme hakkında kusursuz olarak düşünme, belirgin benzerlik ve farklılıklara dikkat etme, sayıltıları inceleme ve değerlendirme, ilgili olmayan gerçeklerden ilgili olanları ayırt etme, akılcı çıkarımlar, tahminler ve yorumlar yapma, kanıtları ve iddia edilen gerçekleri değerlendirme, çelişkilerin farkına varma, çıkarımları ve sonuçları keşfetme becerilerinden oluşmaktadır.

Eleştirel düşünme, insanların başarılı olabilmek için sahip olması gereken çok önemli özelliklerden biridir. Son yıllarda üzerinde tartışılan konu, günlük yaşantısını sürdüren insanların ne düşündüklerinden ziyade ne şekilde düşündükleri ve ne şekilde öğrendikleridir. İnsanların çağımızda olayları araştırmaları, problem çözebilmeleri, yaratıcı düşünebilmeleri, eleştirel bir şekilde düşünebilmeleri ve bunları uygulayabilmeleri oldukça önem taşımaktadır. Böylesine üst düzey bir düşünme becerisinin genelde eğitim programına özelde ise Din Kültürü ve Ahlak Bilgisi öğretim programına yansıtılması önem arz etmektedir. Bu çalışmanın amacı eleştirel düşünmenin Türkiye'deki İlköğretim Din Kültürü ve Ahlak Bilgisi Öğretim Programı'na (2010) yansımasını incelemektir. 
İlköğretim Din Kültürü ve Ahlak Bilgisi Dersi (4-8 sinıflar) Öğretim Programında; Programın Vizyonu, Programın Uygulanmasına İlişkin İlke ve Açılamalar, Programın Temel Yaklaşımı, Öğretim Programı'nın Özellikleri ve Geliştirilmesinde Temel Alınan İlkeler, Programın Yapısı, Öğrenme-Öğretme Süreçleri ve Öğretmenin Rolü gibi bölümler ele alınıp eleştirel düşünmenin ilgili programa yansıması incelenmiştir. $\mathrm{Bu}$ çalışmada, doküman incelemesi yöntemi kullanılmıştır. Doküman incelemesi; araştırılması hedeflenen olgu veya olgular hakkında bilgi içeren yazılı materyallerin analizini kapsar. Eğitim ile ilgili bir araştırmada ders kitapları, öğretim programı, öğrenci ve öğretmen el kitapları, ders ve ünite planları veri kaynağı olarak kullanılabilir (Yıldırım ve Şimşek, 2006, s. 188).

\section{İlköğretim din kültürü ve ahlak bilgisi öğretim programının eleştirel düşünme açısından incelenmesi}

Türkiye'de ilkokul ve ortaokullarda uygulamada olan İlköğretim din kültürü ve ahlak bilgisi öğretim programı, Din Öğretimi Genel Müdürlügünün 20.12.2010 tarih ve 2748 sayılı teklif yazısı üzerine Talim Terbiye Kurulunun 30.12.2010 tarih ve 328 sayılı kararı ile 2011-2012 öğretim yılından itibaren uygulanmak üzere kabul edilmiştir.

Bu bölümde 2010 ilköğretim din kültürü ve ahlak bilgisi dersi öğretim programı eleştirel düşünme açısından incelenmiş ve değerlendirilmiştir. Giriş, programın vizyonu, Programın uygulanmasına ilişkin ilke ve açıklamalar, programın temel yaklaşımı, İlköğretim Din Kültürü ve Ahlak Bilgisi Dersi (4, 5, 6, 7 ve 8. Sınıflar) Öğretim Programı'nın özellikleri ve geliştirilmesinde temel alınan ilkeler, programın yapısı, öğrenme-öğretme süreçleri ve öğretmenin rolü, vb. bölümlere eleştirel düşünmenin ne kadar yansıdığı incelenmiş, tespit edilmiştir.

\section{İlköğretim din kültürü ve ahlak bilgisi dersi (4-8 Sınıflar) öğretim prog- ramı, giriş bölümü}

Programın giriş bölümünde eleştirel düşünmeyle ilgili bazı bilişsel becerilerin vurgulandığı görülmektedir. Programda yer alan "anlama, sıralama, sınıflandırma, sorgulama, ilişki kurma, eleştirme, tahmin etme, 
analiz-sentez yapma ve değerlendirme, bilgiyi araştırma, yorumlama ve zihinde yapılandırma, kendini ifade etme, iletişim kurma, arkadaşlarıyla işbirliği yapma ve tartışma "(MEB, 2010, s.2) gibi üst düzey zihinsel becerilerin öğrenciler tarafından kazanılması hedeflenmektedir. Özden (1998, s.89) bir konunun öğrenilmesi öğrencilerin o konuyla ilgili tanımlama, sinıflama, uygulama, sentez ve değerlendirme yapabilmelerini amaçlamaktaysa anlam taşıyor olduğunu belirtmektedir. Bunların düşünsel etkinlikler olduğunu ve bu şekilde bir öğretim sürecinde öğrencinin düşünmeyi öğrenmeksizin sadece ezberleme yoluyla analiz, sentez ve değerlendirme şeklinde düşüncel becerileri ortaya koyamayacağını vurgulamaktadır.

Giriş bölümünde üzerinde durulan konulardan birisi de İslam'da sormanın, öğrenmenin önemli bir yere sahip olmasıdır. Hz. Muhammed hayatta iken arkadaşları bilmediklerini soruyor ve önerilerde bulunuyorlardı. Hz. Muhammed'in vefatından sonra da bu sistem devam etmiştir. İlk Müslümanlar karşılaştıkları problemleri bulundukları şartlar dâhilinde ele almış ve onları eleştirel bir şekilde incelemiştir. Sonraki dönmelerde ise, karşılaşılan problemlerde o çağın gerektirdiği çözüm önerileri için çalışılmamış, daha önceki hazır çözüm yöntemleri benimsenmiştir. Fakat bu yöntemler o dönem için artık çağın gerisinde kalmıştır (MEB, 2010, s.3).

Din eğitimi bireyleri belirli bir kalıba sokmayı hedefliyorsa, eleştirel düşünmenin üzerinde çok durmaz, öğretilen konuların sorgulanmasına fırsat vermez. Bu tür bir din eğitim süreci din adına doğru ya da yanlış değerleri bireylere empoze eder, onları anlamlandırmadan kabullenmelerini ister. Kalıplayıcı din eğitimi, kendisine aktarılan dini bilgileri pasif bir şekilde ret etmeden, sorgulamadan alır. Olgu ve gerçekleri tanıma, aklı yürütme, zihinsel analizler yapma, sentez ve genellemelere ulaşma, değerlendirme gibi zihinsel işlemlerde bulunamaz. Bu durum öğrencinin taklit yeteneğini geliştirir. Bu süreçte öğretmen, din hakkında doğru bilgilere sahip olan mutlak otorite olarak kabul edilmektedir. Öğretmen tüm bilgileri aktardığı için öğrencinin soru sormasına, eleştirmesine, problem çözmesine gerek yoktur (Aydın, 2008, s.5). Oysaki gün geçtikçe dünya ve insanın değişmesiyle geçmişteki problemlere yenileri eklenmekte ve değişime ayak uydurmak gittikçe zorlaşmaktadır. Bireylere hazır bilgiler sunmak artık bu çağda bireylerin ihtiyaçlarını karşılamaktadır. Burada 
yapılması gereken önemli husus öğrencinin bilincinin gelişmesini sağlayacak şartları oluşturmak ve öğrenciye hayatın problemlerini çözecek yolları bulmasında rehber olmaktır. $\mathrm{Bu}$ da öğrencileri düşünmeye, sorgulamaya, eleştirmeye ve problem çözmeye teşvik etmekle mümkün hale gelir.

İlköğretim Din Kültürü ve Ahlak Bilgisi programının giriş bölümünde eleştirel düşünmenin yapılarından olan "akıl" kavramına vurgu yapılmaktadır (MEB, 2010, s.3). Programa göre din öğretimi sadece bilgi verme amacında olmamalı aynı zamanda öğrencilerin bilgi etme yollarını ve aklını kullanma yeteneğini de geliştirmelidir. Yine programda üzerinde durulan diğer bir husus ise sunulan alternatiflerin incelenebilmesi hususunda öğrencilerin bakış açılarının gelişmesine gereksinim olduğudur (MEB, 2010, s. 3). Öğrenciler; bilginin kim için, hangi amaçla, nasıl bir dünyada kullanılması gerekeceğini sorgulayacak şekilde eğitilmelidir. Bilhassa din öğretiminin esaslarından biri de öğrencilerin inanç ve hayat hakkındaki tercihlerinde özgür olabilmeleridir. Din öğretimi bu amaçlar dâhilinde öğrencilerin kendi akıl yürütme güçlerini kullanmaları suretiyle varlıklar içinde bulunan konumlarını tespit etmesine yardımcı olur. Eleştirel düşünme akıl ilkelerini temel alındığı ve akıl yürütmenin etkin bir şekilde kullanıldığ 1 bir düşünmedir.

Giriş bölümünde eleştirel düşünmeyi ilgilendiren şu bilgilerden bahsedilmektedir: "Kendilerine sunulan alternatifleri inceleyebilmeleri için öğrencilerin bakış açılarının geliştirilmesine ihtiyaç vardır. Öğrenciler körü körüne uygulayıcı olmamalıdır. Onlar, bilginin hangi amaçla, kim için, nasıl bir dünyada kullanılabileceğini sorgulayacak biçimde yetiştirilmelidir. Öğrencilerin, özellikle inanç ve hayat konusundaki tercihlerini özgür olarak yapabilmeleri din öğretiminin esas amacıdır; bilinçli dindarlık da budur" (MEB, 2010, s.3). Burada özellikle eleştirel düşünme açısından önem arz edecek din öğretiminin üç kazanımından bahsedilmektedir. Bu kazanımlar; sorgulama becerisi, gelişmiş bir bakış açısı ve özgürlüktür.

Eleştirel düşünenler sorgulamadıkları takdirde hiçbir anlam ifade etmezler. Soru sorma, derinlemesine inceleme ve görüşlerin altında yatan nedenlere kadar inme eleştirel düşünme faaliyetinin en can alıcı noktasıdır (Paul, Binker, Jensen ve Krelau, 1990, s.56-102). Eleştirel düşünen- 
ler sorgulanmaktan rahatsız olmaz, kırılmaz, korkmaz ve şaşırmazlar. Onlar, iyi soruları bir düşünce deseni oluşturmak için bir fırsat olarak karşılarlar.

İlgili sorunlar hakkında eleştirel düşünmek için farklı görüş açllarının güçlü ve zayıf yönlerini dikkate almalıyız. Başkalarını anlayabilmek için onların yerine kendimizi koymalıyız. Bu özellik, diğerlerinin görüş ve düşüncelerini doğru bir şekilde yeniden yapılandırabilme ve kendi dışımızda olan öncülleri, sayıltıları ve fikirleri yargılayabilme yeteneğiyle bağlantılıdır. Dünya, birçok bakış açısı ve düşünme yoluna sahip toplum ve halktan oluşmaktadır. Akılcı kişiler olarak yetişmek için, farklı halkların ve toplumların çerçeve ve fikirleri içine girmeli, o yönlü düşünebilmeliyiz. (Paul et all., 1990, s.56-102). Eğer, sadece tek bakış açısından düşünürsek, dünyayı gerçekten anlamak mümkün değildir. Bunun dışında, eleştirel düşünürler, kendi davranışlarının diğerlerini etkilediğinin farkındadır ve bundan dolayı kendi davranışlarını diğer kişilerin bakış açılarıyla göz önünde bulundururlar. Olaylara değişik bakış açılarından bakabilme ve değerlendirebilme becerisi entelektüel özgürlükle mümkün olmaktadır.

Eleştirel düşünme bakımından programın giriş bölümünde üzerinde durulan diğer bir husus ise din öğretiminde insana, düşünceye, hürriyete, ahlaki olana ve kültürel mirasa saygılı olunması hususunda yapılan vurgulamalardır. (MEB, 2010, s.3-5). İnsana saygıyı önemseyen bir eğitim anlayışı, onun varlığını, birey olarak değerli oluşunu kabul edip yaptıklarını tanıma ve onlara anlam verme çabası içindedir. Düşünceye sayg1 ise kendi doğrularımızın yansıra başkalarının da doğruları olabileceğini vurgulamaktadır. İnsanların düşüncelerini önemseyip onlara saygılı olma ve onları anlama çabaları eleştirel düşünme becerileri arasinda da yer almaktadır.

Programda vurgulan bu beş temel kavramın üzerinde durduğu husus, din öğretimin artık tamamen ezberletici ve nakilci bir yaklaşım şeklinde yapılmasının mümkün olmadığıdır. Bu bağlamda, öğrencilerin kendileri için sunulan hazır kalıplarla yaşamlarını sürdüremeyeceği programda belirtilmiştir. "Bilinç geliştirme" ve "problem çözme" şeklindeki temel beceriler programda din öğretimiyle ilgili yaklaşımda göz önüne alınmaktadır ve bunlar üst düzey zihinsel beceriler arasında yer alıp eleştirel düşünme için de önem teşkil etmektedir. Din öğretimiyle benimsenmiş 
olan bu yaklaşım, “öğrencinin bilincinin gelişmesini sağlayacak şartları oluşturmak ve öğrenciye, hayatın problemlerini çözebilmesinde yardımcı olacak yolları göstermek" şeklinde ifade edilmektedir (MEB, 2010, s.5). Öğrencilerin karşılaştıkları problemleri içinde bulunduğu çağın gereksinimlerine göre bilinçli bir şekilde çözebilmeleri de din eğitiminin öğrenciye kazandırması gereken becerilerinden biridir.

\section{Programın Vizyonu}

İlköğretim DKAB Programının vizyonunda; öğretmenlerin öğrencilere doğrudan bilgi aktarmaktan ziyade onlara yol göstereceği etkinlikler vasıtasıyla belirli nitelikleri taşıyan Türkiye Cumhuriyeti vatandaşlarının yetişmesine katkıda bulunması üzerinde durulmaktadır. Bunlar; kendini etkili bir şekilde ifade etmek, iletişim kurmak, sorun çözmek, araştırmak ve öğrenmekten zevk almak, sormak, sorgulamak, eleştirmek, dini doğru anlamak ve yorumlamak, kendi dininden ve başka dinlerden olanlara anlayışlı davranmak ve diğer dinleri tanımak şeklinde programda ifade edilmektedir (MEB, 2010, s.8).

"Kendini etkili bir şekilde ifade etmek" ve "iletişim kurmak" eleştirel düşünmenin duyuşsal becerileri arasında bulunmaktadır (MEB, 2010, s. 8). Eleştirel düşünceye sahip bireyler düşüncelerini etkili bir iletişimle, anlaşılır bir şekilde paylaşıp kendilerini etkili bir şekilde ifade ederler (Özden, 2003, s. 161). Eleştirel düşünen öğrenciler düşündüklerini açı ve tutarlı bir şekilde ifade ederler. Kendilerine söylenenleri eleştiri süzgecinden geçirerek etkili tahliller, analizler yaparlar.

Eleştirel düşünme becerilerinden biri de "sorun çözmektir" (MEB, 2010, s. 8). Yıldırım (1997, s.43) düşünmenin her düzeyde ve konuda bir problem ya da sorun çözme etkinliği olduğuna dikkat çekmiş ve düşünme sürecinin iki temel boyuttan oluştuğunu belirtmiştir. Bu boyutlar sorunu açıklayarak veya da gidererek çözüm bulma veya oluşturma ve ilgili çözümdeki doğruluk payını araştırmaktır. Programın vizyonu arasında yer alan "araştırmak ve öğrenmekten zevk almak" eleştirel düşünmenin duyuşsal becerilerinden biridir (MEB, 2010, s.8). Program, din eğitiminde araştıran, güvenilir bilgiyi elde etmede azimli ve öğrenmekten zevk alan öğrencilerin yetişmesini hedeflemektedir. Kendisine söylenene ya da 
okuduğuna hiçbir araştırma yapmadan körü körüne inanan öğrenci portföyünü benimsememektedir.

Programın bir başka vizyonu olarak sormak, sorgulamak ve eleştirmek gösterilmektedir (MEB, 2010, s.8). Sorma, sorgulama ve eleştirme becerileri eleştirel düşünmeyle ilgili becerilerdir. Gürkaynak, Üstel ve Gülgöz'e (2003, s.26) göre öğrencilerin içinde bulundukları okul, çevre ve toplumla ilgili sorgulama ve tartışmalara yönlenmeleri eleştirel düşünme becerilerinin gelişmesi açısından önemlidir. Öğrenciler hayatları boyunca karşılaştıkları durumda olaylara merakla yaklaşır, sorular sorurlar. Olayların nedenini anlamaya çalışır, bunların altında yatan gerçeklerin neler olabileceğini sorgulayıp olaylara farklı bakış açılarından bakabilmeyi öğrenir.

Programın vizyonuna ait bir başka özellik de dini doğru anlamak ve yorumlamak şeklinde ifade edilmektedir (MEB, 2010, s.8). Kur'an' da dinle ilgili ezberlenmiş kalıp bilgilere sahip olup şartlanmaktan ziyade derin kavrayışa sahip olmanın önerildiği görülmektedir (Tevbe 9/122). Kur'an'da ki ayetler de "insanın üzerinde düşünmesi, anlamlandırması gereken bir kelam" şeklinde ifade edilmiştir (Aydın, 2011, s.87-88). Bu sebeple, dini doğru anlamak ve yorumlamak için düşünme sürecini özellikle de eleştirel düşünme becerisini iyi kullanmak gerekmektedir.

Kendi dininden ve başka dinlerden olanlara anlayışlı davranmak ve diğer dinleri tanımak programın vizyonunda yer alıp eleştirel düşünmeyi ilgilendiren unsurlardandır (MEB, 2010, s.8). Öğrencilerin toplumda bulunan farklı yaşayış ve anlayışların sosyal olgular olduklarını bilmeleri ve başka bireylerin yaşayış ve inançlarına hoşgörülü bir şekilde yaklaşmaları programdaki amaçlardan birini teşkil etmektedir. Farklılıklar karşısında anlayış ve hoş görüye sahip olmak eleştirel düşünmenin duyuşsal becerilerinden de biridir. Öğrenciler dünyanın birçok bakış açısı ve düşünme yoluna sahip toplum ve halktan oluştuğunu bilmeli, farklı halkların ve toplumların fikirlerine ve düşüncelerine saygı duymalı, bunların da doğru olabileceği ihtimalini göz ardı etmemelidir (Tosun, 2003, s.260). 


\subsection{Programın Temel Yaklaşımı}

İlköğretim Din Kültürü ve Ahlak Bilgisi Öğretim Programının temel yaklaşımı iki şekilde ele alınmıştır. Bunlardan birincisi eğitimsel yaklaşım, diğeri ise dinbilimsel yaklaşımdır.

İlköğretim DKAB dersi programı eğitimsel açıdan yapılandırmacı yaklaşım, çoklu zekâ, öğrenci merkezli öğrenme gibi yaklaşımlar dikkate alınarak hazırlanmıştır (MEB, 2010, s.9). Programa göre yapılandırmacı yaklaşımda öğrenme aşamasında ön bilgilerin harekete geçirilmesi, etkili iletişim kurulması, anlam kurulması, uygulama ve değerlendirme önemli kavramlardır. Yapılandırmacı yaklaşım öğrenci katılımına önem veren, öğrenci merkezli bir yaklaşımdır. Derslerde öğrenci katılımının sağlanması, öğrencilerin kendi ifade yeteneğini kazanması, öğrencilerin yapıp-etmelerine rehberlik edilmesi, öğrencilerin bilgileri kendilerinin oluşturması hususunsa fırsat tanınması öğrencileri ezberden kurtaracak, edinmiş olduğu bilgileri nerde ve nasıl kullanabileceğini öğretecek, eleştirel düşünebilmelerine olanak tanıyacak, kendi kararlarını kendilerinin verebileceği ders ortamları oluşturmak demektir (Kızılabdullah, 2008, s.64).

İlköğretim DKAB dersi programında kavramsal bir yaklaşımın takip edildiği, din kültürü ve ahlak bilgisi dersi ile alakalı kavram ve ilişkilerin ve problem çözme, iletişim kurma, akıl yürütme, vb. becerilerin geliştirilmesine vurgu yapılmaktadır (MEB, 2010, s.9). Programa göre, kavramsal yaklaşım din ve ahlak hakkındaki bilgilerin kavramsal temellerini oluşturmak için daha fazla yoğunlaşmayı ve bu şekilde kavramsal ve işlemsel bilgiler arasında ilişkiler kurmayı gerek kılmaktadır. Bu şekildeki bir kavramsal yaklaşım vasıtasıyla öğrencilere ait somut sezgi ve deneyimlerden dini ve ahlaki anlamlar oluşturabilmelerine ve soyut düşünmelerine yardımda bulunmak amaçlanmaktadır.

Öğretimde kavramsal yaklaşım eleştirel düşünme için de önemli bir unsurdur. Düşüncenin altında yatan sorularla alakalı gerçeklerin ve belirli kavramların bilinmesiyle eleştirel düşünme etkili bir şekilde öğrenilebilir. Eleştirel düşünme eğitiminin daha etkili olabilmesi için konuyla alakalı kavramların tam olarak öğretilmesi önem arz etmektedir (Patric, 1986). Din eğitiminde de kavramlar açık bir şekilde açılanmalı, günümüz Türkçesinde verilmelidir. Aksi takdirde öğrenciler kavramları ezberleme 
yoluna gidip anlamlı bir öğrenme yolunu seçmeyebilirler. Öğrenilen kavramlar, gündelik yaşantıyla ilişkilendirilmeli, yaşamla ilgili problemlere çözüm yolları aramada öğrencilere yardımcı olmalıdır.

İlköğretim DKAB Öğretim Programı'nda ikinci yaklaşımın din bilimsel yaklaşım olduğu görülmektedir (MEB, 2010, s.10). Programda belirtilen din bilimsel yaklaşımın öğrencilere kazandırması beklenen özellikler incelendiğinde, öğrencilerin eleştirel düşünme becerilerini geliştirebilecek bazı hususlar tespit edilmektedir: İslam düşüncesinde farklı anlayış ve yorum biçimleriyle ilgili bilgiler verilmek suretiyle saygı ve hoşgörüyü temel alıp farklılıkların zenginlik şeklinde görülmesi. Öğrencilerin inançlarını ve kültür dünyalarını genişletmek, onları diğer dinler ve farklı görüşlere sahip olanlar hakkında daha hoşgörülü ve anlayışlı hale getirmek için diğer dinler hakkında genel bilgi verilmesi. Dinin doğru anlaşılması ve yorumlanması hususuna katkıda bulunmak. Öğrencilerin kendilerine güven duygularının geliştirilmesi ve öğrencilerin araştırmaya sevk edilmesi.

Doğruyu arama eleştirel düşünme eleştirel düşünme becerilerinden önemli bir unsurdur. Soru sorma, farklı düşünceler hakkında değerlendirme yapma, düşüncesiyle çelişen konular olduğunda bile nesnel davranabilme becerisini kapsayan bu unsur İslam'ın insanlara kazandırma gayesinde olduğu önemli ahlaki değerlerden biridir (Kökdemir, 2003). Kur'ana göre gerçeği bulma yöntemlerinden biri de insanları ön yargılarımızdan uzak bir şekilde nesnel olarak dinlemek ve anlamaktır. Bu şekilde farklı görüşler eleştirel bir şekilde düşünülerek sorgulanacak ve en doğru olan tercih edilecektir.

Programın din bilimsel yaklaşımları arasında bahsedilen önemli hususlardan biri de öğrencinin güven duygusunun geliştirilmesidir (MEB, 2010, s.11). Kendine güven eleştirel düşünme becerilerinden de biridir. Kendine güven becerisi bireyin kendi akıl yürütme süreçlerine duyduğu güveni belirtmektedir (Kökdemir, 2003). Bir konuyu araştırırken konuyla ilgili detaylı bilgi, dikkatli bir gözlem, değişik bakış açıları, nesnellik ve entelektüel özgürlüğe ek olarak özgüven de gerekmektedir. 


\section{İlköğretim din kültürü ve ahlak bilgisi dersi (4-8 sınıflar) öğretim prog- ramının özellikleri ve geliştirilmesinde temel alınan ilkeler}

İlköğretim Din Kültürü ve Ahlak Bilgisi Dersi Öğretim Programının geliştirilmesinde temel alan ilkelerden eleştirel düşünmeyle ilgili olan hususlar incelenmiştir: “Gerekli ve yeterli bilgi” yaklaşımı; öğrencilerin bilgileri ezberlemekten ziyade üretmeye dayalı bir yaklaşımı benimsemesi; öğrencinin düşünmeye soru sormaya ve görüş alışverişi yapmaya özendirilmesi; öğrencilerin öğrenme sürecinde deneyim kazanıp çevreyle iletişim içinde olmaları; öğrencilerin problem çözme üzerinde yoğunlaşması ve öğrenme sürecinde etkinliklere katılmasının sağlanması; insana, düşünceye, hürriyete, ahlaki olana ve kültüre saygının esas alınması (MEB, 2010, s.11-12) eleştirel düşünmeyle ilgili hususları içermektedir.

"Gerekli ve yeterli bilgi yaklaşımı" programın ilkelerinden olup eleştirel düşünme içinde önemli bir husus sayılmaktadır (MEB, 2010, s.11). "Gerekli ve yeterli bilgi" bilginin doğru ve güvenilir olması ve aynı zamanda gereksiz fazla bilgilerden de kaçınılmasıdır. Eleştirel düşünme, bir sorun hakkında ilgili ve ilgili olmayan gerçekleri ayırt etme duyarlılığını gerektirir. Eleştirel düşünenler ilgili gerçeklere odaklanır ve ilgisiz gerçeklerin kendi sonuçlarını etkilemesine izin vermezler. Ayrıca, bir gerçeğin konuyla bağlantılı olarak ilgili ya da ilgisiz olacağını bilirler.

Öğrencilerin bilgileri ezberlemekten ziyade üretmeye dayalı bir yaklaşımı benimsemesi programın ilkelerinden eleştirel düşünmeyle ilgili diğer bir husustur (MEB, 2010, s.11). Günümüz eğitim anlayışında artık bilgileri depolamaya ve olduğu gibi ezberlemeye değil bilgiyi üretmeye, yorumlamaya, kullanabilmeye, denetleyebilmeye ve yönetmeye odaklanmış insan profiline ihtiyaç duyulmaktadır (İşpiroğlu, 2002). Din öğretiminde de artık ezberci ve nakilci bir yaklaşım ve kendilerine sunulan hazır kalıplar günümüzde öğrencilerin ihtiyaçlarını karşılamayabilir. Öğrencilerin çağımıza ve yeni şeylere uyum sağlamasında ihtiyaç duyacakları esneklik ve becerileri kazanmasında eleştirel düşünme becerilerini geliştirmeleri beklenmektedir.

İlköğretim DKAB Programının eleştirel düşünmeyle ilgili olan bir diğer ilkesi ise "öğrencinin düşünmeye, soru sormaya ve görüş alışverişi yapmaya özendirilmesi” hususudur (MEB, 2010, s.11). DKAB öğretmenlerinin en önemli görevlerinden birisi konular hakkında öğrencilerin 
düşünmesine, incelemesine ve araştırma yapmasına olanak sağlayan etkinlikler düzenleyerek öğrencilerin bilgi elde etme şekillerinin, akıl ve duygularını kullanma yeteneklerinin gelişimine katkıda bulunmaktır (Selçuk, 1998). Merak eden, soru soran öğrenci aynı zamanda düşmekte ve sorgulamaktadır.

“Öğrencilerin öğrenme sürecinde deneyim kazanıp çevreyle iletişim içinde olmaları" ise programda belirtilen ve eleştirel düşünmeyle bağlantısı olan ilkelerden bir başkasıdır (MEB, 2010, s.12). Eğitimi ezbercilikten kurtarmak için öğrenilen bilgilerin insan yaşamı içerisinde bir yeri, bir bağlantısı olması gerekir. DKAB derslerinde öğrenilen konuları ve dini bilgileri günlük hayatında uygulayan, bunları içselleştiren, sosyal bir kişi olmasının gereği çevresiyle iletişim kurup bilgi alışverişinde bulunan öğrencilerin yetiştirilmesine yardımcı olmak DKAB öğretmenlerinin sorumlulukları arasında yer alabilir.

Programın geliştirilmesinde temel alınan ve eleştirel düşünmeyle bağlantılı olan "öğrencilerin problem çözme üzerinde yoğunlaşması ve öğrenme sürecinde etkinliklere katılmasının sağlanması" ilkesi de önem teşkil etmektedir (MEB, 2010, s.12). Toplumda bireylerin eleştirel düşünme ve karar verme becerilerini yüzü yüze geldikleri sosyal problemlerin çözüm sürecinde kullanabilmeleri önemli bir durumdur (Norris, 1985). Bu yüzden, öğrenciler DKAB derslerinde aktif şekilde dini bilgileri ve kavramları öğrenirken problem çözmeye, çözümlerini ve düşüncelerini paylaşmaya, açıklamaya ve savunmaya teşvik edilmelidir.

"İnsana, düşünceye, hürriyete, ahlaki olana ve kültüre saygının esas alınması" ise programın geliştirilmesinde temel alınan ve eleştirel düşünmeyle bağlantılı olan en son ilkelerdir (MEB, 2010, s.12)." İnsana sayg1 "fikrinin temel alındığı bir eğitim anlayışında, insanın ne olduğu üzerinde düşünülür; onun yaptıklarını tanıma, anlam verme, düşüncelerine ve iç âlemine nüfus etme amaçlanır. Programdaki diğer bir ilke olan "düşünceye sayg1;" benim doğrum tek doğrudur, bunun dışındakiler ise yanlıştır fikrinden vazgeçmeyi, önyargılarımızdan kurtulup başka fikirleri de dinleyebilmeyi, fikirler üzerinde düşünebilmeyi ve sorgulayabilmeyi içerir.

"Hürriyete sayg1" ise programın geliştirilmesinde temel alınan önemli bir ilkedir. İnsanlar, kendileri için iyi olan şeyleri kendi doğru bildikleri 
yolda arama hürriyetine sahip olmalıdır. İnsanların bağımsız karar verebilmelerine ve kendi tercihlerinin sahibi olabilmelerine olanak tanınmalıdır. Çeşitliliğin ve fikir zenginliğinin olduğu ortamlarda muhakeme gücü ve seçme kabiliyeti gelişmektedir. Bir başka geliştirilmesi gereken ilke ise "ahlaki olana ve kültürel mirasa saygı" kavramıdır. Çocukların ve gençlerin ahlak eğitiminde dinle temellendirilen bir ahlak anlayışı benimsenebilir. Ahlaklı insan yetiştirmede inanç boyutunun üzerinde durulması gerekebilir. Programın geliştirilmesinde ahlaka saygının yanı sıra "kültürel mirasa saygı" ilkesinden de bahsedilmektedir. Kültürel mirasa saygı, tarihi birikime bakabilmeyi, geçmişin günümüz bakımından yerini, değerini ve görevini tahlil ve tespit edebilmeyi gerektirir. Kültürel mirasa saygı, körü körüne ne geleneği sığınmayı ne de gelenekten kaçmayı gerektirir (Selçuk, 2000). Din eğitiminde önemli olan, öğrencilerin öğrendikleri tüm bu ilke ve bilgileri hayatın problemlerini çözmede kullanabilmeleridir.

\section{Öğretim programını yapısı}

Programın giriş bölümünde eleştirel düşünmeyle ilgili bazı bilişsel becerilerin vurgulandığı görülmektedir. Programda yer alan "anlama, sıralama, sınıflandırma, sorgulama, ilişki kurma, eleştirme, tahmin etme, analiz-sentez yapma ve değerlendirme, bilgiyi araştırma, yorumlama ve zihinde yapılandırma, kendini ifade etme, iletişim kurma, arkadaşlarıyla işbirliği yapma ve tartışma “(MEB, 2010, s.2) gibi üst düzey zihinsel becerilerin öğrenciler tarafından kazanılması hedeflenmektedir.

\section{Genel amaçlar}

İlköğretim DKAB Öğretim Programının genel amaçlar bölümünde yer alan "Dinî kavramları doğru anlayıp kullanma." "Doğru dinî bilgiler ile batıl inanç ve hurafeleri ayırt etme." "Aklın, dinî sorumluluğun temel şartı olduğunu, dinin aklın kullanılmasını istediğini kavrama." "Toplumdaki farklı dinî anlayış ve yaşayışların sosyal bir olgu olduğu bilincine varma." "Başkalarının inanç ve yaşayışlarına hoşgörü ile yaklaşabilme." "Toplum içindeki hurafelere dayalı sağlıksız dinî oluşumları ayırt etme." "Doğru dinî bilgiler yardımıyla nesiller arası anlayış farklılıklarına 
sağlıklı bir şekilde yaklaşma." "Diğer dinleri temel özellikleriyle tanıyarak mensuplarına hoşgörüyle yaklaşma" gibi maddelerin eleştirel düşünmeyle ilgisi bulunmaktadır (MEB, 2010, s.12-13).

Programım amaçları bölümünde yer alan, "kavramların doğru anlaşılması" özelde ise "dini kavramların doğru anlaşılması" eleştirel düşünme becerilerinden biridir (MEB, 2010, s.12). Kavranmalar, insan düşüncesine ait temel taşlarından biridir (Tosun ve Doğan, 2005, s. 1). "Kavramlar, sözcüklere, sembollere ve kendi aralarındaki ilişkilere yüklenmiş anlamlardır" (Klausmeier, 1958, s.75). Dolayısıyla etrafımızdaki olgular kavramlaştırıldığı zaman onlar hakkında düşünülebilir. DKAB dersindeki muhteva ele alındığımda, dini kavramların öğretim konuları içinde önemli bir yere sahip olduğu görülebilir.

Programın amaçlarından biri olan, "Doğru dinî bilgiler ile batıl inanç ve hurafeleri ayırt etme" de eleştirel düşünme becerileriyle ilişkilidir (MEB, 2010, s.12). Doğruluk, ilgililik, kesinlik ve güvenilirlik eleştirel düşünme becerileri arasında yer almaktadır (Paul ve Elder, 2002, s.71-74). Din adına birçok batıl ve hurafe bilgilerin bulunduğu çağımızda, din eğitimin esas amacı, karşılaşılan bilgileri eleştiri süzgecinden geçirip doğru ve ilgili bilgileri elde etmede öğrenciye yardımcı olmaktır. Bu bağlamda, dini doğru anlayıp bilgimizi çoğaltmak ve mantık çerçevesinde düşünüp olaylara değişik bakış açılarından yaklaşmak önem teşkil eder.

"Aklın, dinî sorumluluğun temel şartı olduğunu, dinin aklın kullanılmasını istediğini kavrama" programın amaçlarından bir diğeridir (MEB, 2010, s.12). "Aklın kullanılması" eleştirel düşünmede de üzerinde durulan bir olgudur, çünkü eleştirel düşünme bir akıl yürütme sürecidir (Doğanay ve Ünal, 2006). Dinin muhatap kıldığı ve iman mesuliyeti yüklediği kişiler akıl sahibi insanlardır. Aklı kullanmak ve düşünerek karar vermek önem teşkil eder. İnsanlar düşünerek iyiyi kötüden ve doğruyu yanlıştan ayıt edebilirler. Akıl sahibi insan düşünür, sorgular, araştırır ve karar verir.

Programın amaçlarından olan, "Toplumdaki farklı dinî anlayış ve yaşayışların sosyal bir olgu olduğu bilincine varma" eleştirel düşünme ile ilgisi olan diğer bir maddedir (MEB, 2010, s.13). DKAB derslerinde öğrencilerin, İslam dinin anlaşılabilmesi hususunda çeşitli anlayış ve yorumların oluştuğunu bilmesi ve buradan da dininin anlaşılabilmesi hususunda dinsel yapıda tek tip bir anlayışın mevcut olmadığını kavraya- 
bilmesi amaçlanmaktadır (Doğru, 2018, s.145). Toplumdaki bu farklı anlayış ve yorumların sosyal bir olgu olduğu, bir konu hakkındaki farklı bakış açılarının olabileceği öğrenciler tarafından doğal karşılanmalıdır.

Programda bahsedilen bir başka amaç ise "Başkalarının inanç ve yaşayışlarına hoşgörü ile yaklaşabilme" şeklinde ifade edilmiştir (MEB, 2010, s.13). "Hoşgörüyle yaklaşma" kavramı eleştirel düşünmeyle ilgilidir. Eleştirel düşünme, demokrasi ve hoş görünün oluşumunda ve devamlılığında önemli rol oynar (Halpern, 2003, s.4). Eleştiren, sorgulayan, farklı bakış açlarına saygı duyan toplumlarda demokrasi ve hoşgörü gelişebilir. Bireylerin kendi dini anlayışlarının başkalarına dayatılıp kabul ettirilmesinden ziyade, toplumda farklı inanç, anlayış ve yorumların da olabileceği hakikatinin DKAB derslerinde öğretilmesi amaçlanmaktadır. $\mathrm{Bu}$ şekilde, toplumda ötekileştirme, hoşgörüsüzlük, yok sayma gibi kavramların önüne de geçilebilir.

"Toplum içindeki hurafelere dayalı sağlıksız dinî oluşumları ayırt etme" maddesi de programın amaçlarından olup eleştirel düşünmeyle ilgilidir (MEB, 2010, s.13). Bu maddenin eleştirel düşünmeyle ilgisi yukarıda "Doğru dinî bilgiler ile batıl inanç ve hurafeleri ayırt etme" maddesinde ele alınmıştır. Daha önceden verilmiş bilgiler dışında be madde için eleştirel düşünme becerilerinden olan "Bilgi kaynaklarının güvenirliğini değerlendirme" ve "İlgili olmayan gerçeklerden ilgili olanları ayırt etme" hususları irdelenebilir. Eleştirel düşünenler, sonuçları düzenlerken, güvenilir bilgi kaynağı kullanımının ne kadar önemli olduğunu bilirler. Eleştirel düşünenler, sorunla ilgili alınması gereken birden fazla mantıklı durum olduğunda kabul gören noktaları not ederek değişik bilgi kaynaklarını karşılaştırır ve kaynakların çeliştiği noktalarda daha çok bilgi toplar (Paul vd., 1990, s.56-102). Eleştirel düşünme, bir sorun hakkında ilgili ve ilgili olmayan gerçekleri ayırt etme duyarlılı̆̆ını gerektirir.

"Doğru dinî bilgiler yardımıyla nesiller arası anlayış farklılıklarına sağlıklı bir şekilde yaklaşma" maddesi programın amaçlarından olup aynı zamanda eleştirel düşünmeyle de ilişkilidir (MEB, 2010, s.13). Bu maddeyle ilgili, programın amaçlarından olan "Toplumdaki farklı dinî anlayış ve yaşayışların sosyal bir olgu olduğu bilincine varma" maddesini açıklarken yukarıda gerekli bilgi verilmiştir. Yine burada eleştirel 
düşünme becerilerinden olan "bilgi kaynaklarının güvenirliğini değerlendirme" ve "belirgin benzerlik ve farklılıklara dikkat etme" maddeleri ön plana çıkmaktadır. "Bilgi kaynaklarının güvenirliğini değerlendirme" becerisi yukarıda açıklanmıştır. "Belirgin benzerlik ve farklılıklara dikkat etme" becerisi için şunlar söylenebilir: Eleştirel düşünmeyenler, sıklıkla belirgin benzerlik ve farklılıkları göz ardı ederler. Yüzeysel olarak benzer olan şeyler genellikle önemli ölçüde farklıdır. Yüzeysel olarak farklı olan şeyler ise genellikle temelde aynıdır (Paul vd., 1990, s.56-102). Bu bağlamda, bilgileri doğru ve güvenilir kaynaklardan alabilmeleri ve nesiller arası süregelmiş anlayışlardaki belirgin benzerlik ve farklılıklara dikkat edebilmeleri hususunda DKAB derslerinde öğrencilere rehber olmak gerekmektedir.

Programın amaçları kısmında eleştirel düşünme becerileri ile ilgili son maddemiz ise "Diğer dinleri temel özellikleriyle tanıyarak mensuplarına hoşgörüyle yaklaşma" şeklindedir (MEB, 2010, s.13). Eleştirel düşünürler, yalnızca kendi fikirlerinin tek doğru olduğunu savunup, bunları başkalarına dayatmazlar. Kendi inancı ve görüşü dışındaki her şeyi sapkın kabul etmezler. Aksine, diğer farklı dine mensup insanların dinleri hakkında temel özellikleri öğrenerek onların günlük hayatta kullandıkları kelime, uygulama ve ibadet çeşitliği hakkında bilgi sahibi olarak onlara saygı ve hoşgörü ile yaklaşır.

\section{Öğrenme alanlan}

İlköğretim DKAB dersi, “İnanç, İbadet, Hz. Muhammed, Kur'an ve Yorumu, Ahlak, Din ve Kültür" den meydana gelen altı öğrenme alanı kapsamında yapılandırılmıştır. İlköğretim DKAB Programı Öğretim Programı öğrenme alanları belirlenme sürecinde göz önünde bulundurulan özelliklerden, “Öğrencinin ilgisini çekmesi, öğrencilerde merak ve araştırma isteği oluşturması" ve "Öğrenmede derinliği ve genişliği teşvik etmesi" maddeleri eleştirel düşünme becerileri ile ilgili görünmektedir (MEB, 2010, s.13). "Meraklllı" bireyin bilgi edinme ve yeni şeyler öğrenme eğilimini gösterir (Facione ve Facione, 2010). Yeni bilgiler elde edip bunları öğrenmeye istekli olma durumudur. 
Bunlara ek olarak, eleştirel düşünme becerilerini oluşturan normlardan "derinlik" ve "genişlik" kavramlarından da öğrenme alanlarında bahsedilmektedir. Düşüncenin yeteri kadar "derin" olması için, konunun yüzeyinin altının irdelenmesi, konuya temel olan karmaşık yönlerin tanımlanması ve sorunun temeli olan konuların yeterli düzeyde ele alınması gerekir (Nosich, 2001). Cevabınızın sorunun karmaşık yönleri ile ilgili nasıl bir açıklamayı içerdiği, konunun sadece yüzeysel mi yoksa derinlemesine bir düşünce şeklinde mi ele alınışı önem arz etmektedir. Eleştirel düşünmeyle ilgili diğer bir husus ise "genişlik" kavramıdır. Bir düşüncenin yeteri kadar "geniş" olması için, değişik bakış açılarıyla ve problemlerle ilgilenmek, bunları tanımlamak ve mantık yürütme sürecinde bunları göz önünde bulundurmak gerekir (Nosich, 2001). Bir konuyu farklı bakış açılarından düşünmek eleştirel düşünmede önemli bir husustur. Bizim doğrularımızın yanında başkalarının da doğrularının olabileceğini göz ardı etmediğimiz sürece hoşgörü, anlayış, değişik fikirlere saygı ve empati kavramlarının yaşatıldığı daha sağlıklı toplumlardan bahsedilebilir.

İlköğretim DKAB Programında her bir öğrenme alanını içeren kazanımlar ve ilgili kazanımlar ile ulaşılacak hedefler ifade edilmiştir. Programa göre "inanç" öğrenme alanı ile ilgili hedefler incelendiğinde bazı maddelerin eleştirel düşünme ile ilgili olduğu tespit edilmektedir. Öğrencinin "akıl sahibi, özgür ve inanan bir varlık olduğunun bilincine varabilmesi;" "inandığına bilerek inanması;" "yaşamını anlamlandırması, Allah tarafından gönderilen Peygamberlerin ve getirdikleri vahyin amaçlarını irdeleyebilmesi" ve "diğer inanç sahiplerine saygılı olması" eleştirel düşünmeyle ilgili hususlardır (MEB, 2010, s.14-15). Eleştirel düşünebilmek için akıl sahibi olmak ve düşünebilmek ilk şarttır. Halpern (2003, s.5) eleştirel düşünmeyi olayların ve olguların incelenip akıl süzgecinde geçirilmesi süreci olarak açıklamaktadır. Bireylerin ne yapacağına ve nelere inanacağına karar vermede akıl önemli rol oynamaktadır. Aklıyla hareket eden bireyler özgür ve bilinçli bir şekilde düşünebilmeli ve inanabilmelidir. Eleştirel düşünme özgür ve bilinçli bir şekilde düşünmeyi gerektirir.

İnanç alanını ile ilgili diğer bir hedef de "Allah tarafından gönderilen Peygamberlerin ve getirdikleri vahyin amaçlarını irdeleyebilme" madde- 
sidir (MEB, 2010, s.14). Buradaki "irdeleyebilme" bir konunun incelenmesi ve eleştirilmesi gereken bütün yönlerini birer birer inceleme ve araştırma eylemi olup eleştirel düşünmeyle ilgisi bulunmaktadır. Eleştirel düşünmenin özünde de inceleme ve araştırma mevcuttur (Kurfiss, 1988). Eleştirel düşünmenin ilgili olduğu hedeflerden biri de "diğer inanç sahiplerine saygılı olma" maddesidir (MEB, 2010, s.15). Bireylere saygılı olma ve farklı düşüncelere karşı hoşgörü ile bakma eleştirel düşünme becerileri arasında yer alır. Birlikte, işbirliği içinde çalışabilmek için bizim doğrularımızın yanında başkalarının da doğruları olabileceğine inanmak gerekir.

İlköğretim DKAB Programında "ibadet" öğrenme alanında "insanların, din vicdan ve ibadet hürriyetine saygı duyar" maddesindeki kazanım eleştirel düşünmeyle ilgilidir (MEB, 2010, s.15). Çalışmamızdaki diğer bölümlerde de bahsedildiği üzere, başkalarının görüşlerini dinleme, onlara saygı duyma, değişik görüşleri anlamaya çalışma eleştirel düşüme becerileri arasında yer alır. Birlikte yaşamın gerektirdiği en büyük ilke başkasının inancına saygı duyup ona inandığını yaşama hakkı vermektir (Osmanoğlu, 2012, s.58).

"Hz. Muhammed" öğrenme alanı hedefleri kapsamında bulunan "Hz. Muhammed'in söz ve davranışlarından ilkeler çıkarma bilinci kazanabilmek ve öz eleştiri bilinci kazanabilmek" eleştirel düşünme becerileriyle ilgili maddelerdir (MEB, 2010, s.16). "Çıkarımda bulunma" eleştirel düşünme becerileri arasında yer alır. Mantıklı sonuçlar elde etmek için gerekli olan bilişenlerin tanımlanması, hipotez ve tahminlerin şekillenmesi, konuyla alakalı bilgilerin göz önünde bulundurulması ve ilgili verilerden hareketle sonuca ulaşılması "çıkarımda bulunma" sürecini açıklamaktadır (Facione, 1998, s.5). Eleştirel düşünme, gözlem ve bilgiye dayalı güvenilir sonuçlara ulaşma yeteneğini içerir.

Programdaki “Kur'an ve Yorumu” öğrenme alanında "Kur'an'ın ihtiyaç duyulduğu zaman yorumlanması, bu yorum çerçevesinde hayatın problemlerine çözüm üretilmesi gerekmektedir" şeklinde bilgi verilmektedir (MEB, 2010, s.16). Buradaki "yorumlama" ve "hayatın problemlerine çözüm üretme "eleştirel düşünmeyle ilgili becerilerdir. "Yorumlama" bir "durum, deneyim, veri, olay, yargı, inanç, kural ya da ölçütün" önem ya da anlamının ifade edilme hususudur (Facione, 2000). Bir olay ya da duruma anlam vermek için sunulan bilgilerin değerlendirip 
bir karara varılması gerekir. "Kur'an ve Yorumu" öğrenme alanında eleştirel düşünme ile ilgili diğer bir beceri ise "çözüm üretmek" ya da "hayatın problemlerine çözüm üretmek" şeklinde yer almaktadır.

"Kur'an ve Yorumu" öğrenme alanında hedeflenen kazanımlardan "Kur'an'daki kıssaların yer almasının nedenlerini kavrar ve bu kıssalardan hisse çıkarma bilincine varır", "İslam'ı öğrenmekte Kur'an'ın en önemli kaynak olduğu, onun açılayıcı ve yol göstericiliğinin anlamını, iyiliğe yönlendirip kötülükten sakındırmasını, hayatımızdaki önemini açılar", "Dini anlamada ve sorumlu olmada aklın önemini, Kur'an'ın akla ve doğru bilgiye verdiği önemi, bilgi edinme yollarını, her türlü taassubun ve din istismarının zararları hakkında bilgi sahibi olur" ve "Din ve din anlayışındaki yorum farklılıklarını ve ortaya çıkış sebeplerini, inanç, amel ve ahlakla ilgili yorum çeşitlerinin bir zenginlik olduğunu ve bunların nedenlerini sorgulayarak her zaman ve mekânda ihtiyaç duyulduğunda yeni yorumların kaçınılmaz olduğunu fark eder" maddelerinin eleştirel düşünme becerileri ile ilgisi bulunmaktadır (MEB, 2010, s. 16-17). Bu kazanımlar arasında yer alan "hisse çıkartma, aklını kullanma, doğru bilgiye ulaşma, yorum farklılıklarını anlama, sorgulama ve fark etme" eleştirel düşünme becerileriyle ilişkili olan hususlardır.

Facione (1990) "sonuç çıkarmanın" eleştirel düşünme becerilerinden biri olduğunu belirtmektedir. Pascarella ve Terezini (1991), eleştirel düşünmeyi eldeki bilgiler kapsamında sonuçların yorumlanması ve sonuçlar çıkarılması şeklinde açıklamaktadır. Eleştirel düşünmede amaç, bir konuda var olan verileri değerlendirip bunlardan mantıklı sonuçlar çıkarmaktır. Mantıklı sonuçlar elde etmek "akıl yürütme" vasıtasıyla gerçekleşebilir. "Aklı yürütme" de eleştirel düşünme becerileri arasında yer alır (Gündoğdu, 2009). Bilginin kaynağı akıldır ve doğru bilgiye ancak akıl ve düşünce yoluyla varılabilir (Topçu, 2005).

"Kur'an ve Yorumu" öğrenme alanında hedeflenen kazanımlardan eleştirel düşünme becerileriyle ilgili diğer bir madde ise "yorum farklılıklarını anlama" şeklindedir. Tosun' a göre, (2003, s.260) "farklıklara karşı anlayışlı ve hoşgörülü" olmak eleştirel düşünme becerilerinden biridir. Öğrenciler, DKAB derslerinde özellikle farklı olaylara değişik açılardan bakabilmeyi ve kendisi gibi düşünmeyen insanların da görüşlerinin doğru olabileceğini öğrenmelidir. Eleştirel düşünmeyle ilgili olan diğer bir madde ise "sorgulama ve fark etme" becerisidir. Şahinel (2001) eleştirel 
düşünmeyi "tanımları, eylemleri ve inançları sorgulama" şeklinde tanımlar. Olaylara, bilgilere körü körüne pasif bir şekilde inanmak yerine, bunları neden, niçin ve nasıl soruları aracılığıyla sorgulamak ve araştırmak eleştirel düşünmenin bir gereğidir.

"Ahlak" öğrenme alanındaki kazanımlar incelendiğinde, "Dinimizin sakınmamızı istediği davranışlar ve kötü alışkanlıkların bireysel ve toplumsal zararlarını irdeler ve bunlara çözümler üretir" maddesinin eleştirel düşünme ile ilgili olduğu görülebilir (MEB, 2010, s.17). Bu maddedeki "irdelemek ve çözümler üretmek" eleştirel düşünme becerileri olarak bilinmektedir (Şahinel, 2001). "İrdeleme" becerisi, bir sorunun ele alınabilen bütün durumlarını, bir konunun bütün yönlerini araştırıp birer birer incelemek anlamına gelmektedir. Çözümler üretmek" ise "problem çözme becerisi" ile ilgilidir. Özellikle, günlük hayatta karşılaşılan problemlere çözümler üretmek, çeşitli alternatiflerden uygun olanı seçmek eleştirel düşünme için önemli bir adımdır.

"Din ve kültür" öğrenme alanında eleştirel düşünme ile ilgili kazanımlar şunlardır: "Anne ve babaların daima çocuklarının iyiliğini istediğini fark eder", "Aile içindeki sorumluluklarının bilincinde olur ve aile içi sorunlara birlikte çözüm üretir", "Türklerin Müslümanlaşma süreçlerini araştırır", "Türklerin İslam medeniyetine ve bilime olan katkılarını fark eder", "Laikliğin akla ve bilime önem vermesinin önemini anlar", "Evrensel değerlerin anlamını kavrar", "Farklı inanç sahiplerine sayg1 duyar" (MEB, 2010, s.18). Adı geçen kazanımlarda geçen, "farkında oma, problemlere çözüm üretmek, araştırmak ve önemini anlamak" eleştirel düşünme becerileri arasında yer almaktadır.

\section{Öğrenme-Öğretme süreçleri ve öğretmenin rolü}

İlköğretim DKAB Öğretim Programında, “öğrenme-öğretme süreçleri ve öğretmenin rolü" bölümü incelendiğinde, bazı hususların eleştirel düşünme becerileri ile ilgili olduğu görülmektedir. Mevcut bilgilerin hızla eskimesi ve yerine yeni bilgilerin gelişmesinden dolayı öğrencilere bilgi aktarma yaklaşımı önemini yitirmektedir. Öğrencinin bilgiyi güncelleştirebileceği ve aktif olabileceği bir eğitim süreci önem teşkil etmektedir. Bu eğitim sürecinde, öğrencinin düşünebileceği, sorgulayabileceği, 
araştırabileceği ve bilgiyi kendine göre yapılandırıp günlük hayatta kullanabileceği sınıf ortamları oluşturulmalıdır (MEB, 2010, s. 24).

Halpern, (2003, s.17) eleştirel düşünme becerilerinin öğrencilere kazandırılması için onların rahat ve bağımsız bir şekilde düşünebilecekleri, sorgulayarak durum ve problemler için çözüm yolları bulabilecekleri, olaylara farklı bakış açlarından bakabilecekleri, fikirlerini rahat bir şekilde ifade edebilecekleri aktif bir şekilde düşünmelerine yardımcı olacak bir sinıf ortamına gereksinim duyulduğunu belirtmiştir. Verilen bilgilerden de anlaşıldığı gibi, eleştirel düşünme; aktif, sorgulayan, araştıran, bağımsız bir şekilde düşünmeye yönlendiren ve problemlere çözüm yolları arayan sınıf ortalarına gereksinim duyar.

İlköğretim DKAB Öğretim Programında, öğrenme ortamlarında öğrencide "merak" duygusunu uyandırılması gerektiği de belirtilmektedir (MEB, 2010, s.24). Facione'ne (1998) göre "meraklılık" eleştirel düşünme boyutları arasında yer almaktadır. "Meraklı olmak" bireyin düşünsel olarak meraklı ve istekli olma durumudur. Eleştirel düşünme öğretiminde öğretmenlere düşün görevler arasında öğrencilerin merak duyularını geliştirmek de yer almaktadır (Gök ve Erdoğan, 2011). Merak ve kuşku araştırmayı ve düşünceyi tetikler. İnsanlar merak duydukları şeyleri sorgular, araştırır ve onlar hakkında eleştirel bir şekilde düşünür. Programda belirtilen diğer bir husus ise öğrenci merkezli sinıflarda öğretmenler kendi kararlarını dayatmak yerine öğrencilere rehber olmak, öneriler sunmak, gerektiğinde açıklamalarda bulunup fikir beyan etmek ve onların gelişimlerini takip etmek durumundadır.

Öğrencilerin çeşitli öğrenme deneyimlerine sahip olabilmesi için DKAB öğretim sürecinde uygun öğrenme ortamlarının sağlanmasına ihtiyaç duyulur. Öğrencilerin olayları değerlendirmede bulunacakları bireysel ve grup çalışmaları etkin olarak öğretim sürecinde kullanılmalıdır (MEB, 2010, s.25). "Analiz etme" eleştirel düşünme becerilerinden biridir (Facione, 1990, s.4). "Analiz etme" verilen nedenler 1şığında elde edilen sonucun doğruluğunun çözümlenmesi sürecidir. Bu hususta da, nedenlerin kabul edilebilirliği şarttır (Halpern, 1996). Eleştirel düşünme; analiz, sentez ve değerlendirme gibi üst düzey düşünmeyi gerektirir.

2010 İlköğretim DKAB Öğretim Programında belirtilen diğer bir husus ise öğrencilerin anlamlı öğrenme sürecinden geçebilmeleri için etkinliklerin kendilerini düşünmeye sevke etmesi gerekmektedir. Önlerindeki 
yazıları, dinledikleri bilgileri, ya da şekilleri olduğu gibi aktarmak öğrencileri etkin kılmaktan ziyade onları ezberciliğe itmektedir. Oysaki anlamlı bir öğrenmenin gerçekleşmesi için öğrenci, bir bilim adamı gibi, karşılaşılan problemlerle ilgili açık uçlu sorular sorarak araştırma ve sorgulama yöntemini kullanır. Böylece öğrenci din ve ahlaka yönelik bilgileri hayatın içinde kullanabilir. Bu süreçte öğretmen, bir rehber görevinde olup öğrencilerin motivasyonuna yardımcı olur, gerekli yerlerde devreye girerek öğrencinin yararı için yeni ve özgün ortam hazırlayıp sürekli araştırma gayretinde olur (MEB, 2010, s.25). Bonwell ve Eisone'a (1991) göre, aktif öğrenmenin gerçekleşmesi için öğrencilerin düşünmeye teşvik eden etkinliklerle uğraşması gerekmektedir.

İşbirlikli öğrenme yöntemlerinin DKAB derslerinde kullanılması yine 2010 İlköğretim DKAB Öğretim Programında tavsiye edilen hususlardan biridir (MEB, 2010, s.25-26). İşbirlikli öğrenme esnasında öğrenciler genelde gruplar halinde işbirliği içinde çalışıp diğerlerinin bakış açılarını, alternatif görüşlerini ve fikirlerini değerlendir, araştırır, eleştirir, problem çözer, öğrendiklerini uygular ve geri bildirimler verir (Tang, 1998, s.116). $\mathrm{Bu}$ anlamda, birbirine karşı saygı ve hoşgörü içinde çalışıp birbirinin fikrine saygı duyan, çeşitli bakış açılarını irdeleyen, eleştiren, araştıran aktif öğrenciler eleştirel düşünme becerilerini daha kolay bir şekilde edinebilirler.

2010 İlköğretim DKAB Öğretim Programında, sınıf içindeki etkinlikler esnasında öğretmenin rolü hakkında eleştirel düşünmeyle ilgisi bulunan bazı bilgiler verilmiştir (MEB, 2010, s.26). "Öğrencilerin fikirlerini önemseyiniz" maddesi eleştirel düşünmeyle ilgilidir. Öğrencilerin aktif katılımını teşvik eden öğrenci merkezli eğitim sistemi eleştirel düşünmeye dayalı bir eğitim süreci için etkili olmaktadır (Lipman, 2013, s.12). Bu süreçte öğrencelerin fikirlerinin öğretmenler tarafından önemsenmesi, öğrencilerin fikirlerini rahatça ifade etmelerini sağlayabilir ve öğrenciler aktif bir şekilde bağımsız düşünüp farklı düşüncelere de saygı duyabilir.

Öğretmenin rolü hakkında eleştirel düşünmeyle ilgisi bulunan diğer bir madde ise "Öğrencilerin işlenen konu ile ilgili ön bilgilerini açığa çıkarın ve öğrencilerin kendi düşüncelerinin farkında olmalarını sağlayınız" şeklinde yer almaktadır (MEB, 2010, s.26). Yeni bilgiler ve beceriler verilmeden önce öğrencilerin ön bilgileri açığa çıkarılmalıdır. Ancak bu şekilde yeni bilgiler eski bilgilerle ilişkilendirilir ve anlamlı 
öğrenme meydana gelebilir (Güneş, 2007, s.272). Yeni öğrenilen bilgilerle daha önceden öğrenilenler arasında ilişki kurma ve buna bağlı olarak anlamlı bir öğrenme sürecinin başlaması eleştirel düşünmenin gerektirdiği bir öğrenme yöntemidir.

“Tartışmaları ve etkinlikleri, öğrencilerin bilgi ve anlayışları kendilerinin yapılandırmasına imkân verecek şekilde yönlendiriniz" DKAB öğretim Programında eleştirel düşünmeyle ilgili yer alan bir diğer maddedir (MEB, 2010, s.26). Öğrenci, kendisine sunulan bilgi ve anlayışları olduğu gibi kabul etmek yerine, tartışmalar ve etkinliklerde ön planda olup "neden" sorusunu kendisine sorarak eleştirel bir şekilde kendisine sunulan bilgiyi araştırır ve eldeki verileri zihin süzgecinden geçirip kendine göre bir anlam verir (Karagöz, 2012, s.23). Bu bağlamda öğrencinin ön planda tutulduğu, öğrencinin aktif şekilde öğrenme etkinliklerine katıldığı, öğrenci merkezli bir eğitim benimsenmektedir. Öğrenci artık pasif bir şekilde bilgiyi alan değil, bilgiye ulaşan, bilgiyi denetleyen ve onu yapılandıran konumundadır.

Programda yer alan "Bir öğrenme görevi oluştururken gerçek yaşamda karşılaşılan düzeyde karmaşık olmasına dikkat ediniz" maddesinin de eleştirel düşünmeyle ilgisi bulunmaktadır (MEB, 2010, s.26). Eleştirel düşünme becerilerine sahip bireyler, sahip oldukları eleştirel düşünme becerilerini karşılaşmış oldukları hayatın karmaşık problemlerini çözmede kullanabilirler (Norris, 1985). Öğrencilerin, hayatın içinde karşılaştıkları karmaşık problemleri etkili bir şekilde çözüp doğru ve akılcı kararlar alabilmeleri için eleştirel düşünme becerilerine sahip olmaları gerekir.

\section{Sonuç}

Sonuç olarak, 2010 yılında uygulamaya giren İlköğretim Din Kültürü ve Ahlak Bilgis öğretim programında yer alan giriş, programın vizyonu, Programın uygulanmasına ilişkin ilke ve açıklamalar, programın temel yaklaşımı, İlköğretim Din Kültürü ve Ahlak Bilgisi Dersi $(4,5,6,7$ ve 8 . Sınıflar) öğretim programı'nın özellikleri ve geliştirilmesinde temel alınan ilkeler, programın yapısı, öğrenme-öğretme süreçleri ve öğretmenin rolü bölümler eleştirel düşünme açısından incelenmiş ve analiz edilmiştir. Bu analiz ve incelemeye bağlı olarak, eleştirel düşünme becerilerinin öğretim 
programının merkezinde yer aldığı görülmektedir. Eleştirel düşünmenin Din Kültürü ve Ahlak Bilgisi öğretim programının bir parçası olması öğrencilerin bilinçlerinin gelişmesi hususunda ve yaşamda karşılaştıkları problemlere çözüm yolları bulabilmelerinde önem teşkil etmektedir. Ayrıca eleştirel düşünmenin eğitim programında öğretilmesi öğrencilerin barış, sevgi, hoşgörü geliştirmelerine imkan tanıyıp öğrencilerde farklı fikirlere, inançlara yaklaşımlarında daha esnek ve insancıl tutumlar geliştirecek, olaylara farklı açlardan bakabilmeyi teşvik edecektir. Düşünen, sorgulayan, analiz, sentez, değerlendirme gibi üst düzey zihinsel becerilerini kullanan öğrenciler karşılaştıkları bilgileri pasif bir şekilde körü körüne kabul etmeyecek, zihinlerinde eleştirel düşünme süzgecinden geçirip mantıklı çıkarımlar yapacaklardır.

DKAB derslerinin en önemli sorumluklarından biri çağımızda karşılaşılan sorunlara hazır kalıp çözümler uygulamaktan ziyade eleştirel düşünme becerilerini kullanarak yaşadığımız çağın da özelliklerini dikkate alarak çözümler üretmek, gerektiğinde görüş alışverişinde bulunup demokratik ortamlarda tartışabilmektir. 


\title{
EXTENDED ABSTRACT
}

\section{An Investigation of the Curriculum of Religious Culture and Morality in terms of Critical Thinking Skills}

\author{
Eyyup Serkan Öncel
}

\author{
Osmaniye Korkut Ata University
}

In this study, it has been examined and evaluated how critical thinking skills are reflected in religious culture and ethics curriculum (2010) for primary and secondary schools. In this evaluation process, document review method has been used. While making the determinations and investigations, literature review, similar studies, academic journals and articles were used.

In the "introductory part of the program", students will be able to get some critical thinking skills such as understanding, sorting, classifying, questioning, relating, criticizing, predicingt, analyzing and synthesizing and evaluating information, researching and interpreting information and constructing in mind, expressing themselves, communicating, collaborating with friends and discussing. (MEB, 2010, p.2). The basic approach of the program is handled in two ways as educational approach and theological approach. It is stated that the curriculum is prepared by considering approaches such as multiple intelligence and student centered learning in terms od educational approach. Students will be able to learn concepts and relationships related to religious culture and ethics course and the development of some critical thinking skills such as problem solving, communication, reasoning, etc. attention will be focused on (MEB, 2010, p.9). When the features related to the theological approach for the students to be gained examined, some critical thinking skills can be seen to be developed such as seeing diffrences as wealth by basing on respect and tolerance, expanding students' beliefs and cultural worlds and giving students general knowledge about other religions to make them tolerant and understanding. 
When the features of the curriculum and the principles that are based on the development of the curriculum are examined, the identified skills and attitudes related to critical thinking skills are: Necessary and adequate information approach, students' adopting a production-based approach rather than memorizing information, encouraging students to think, ask questions and exchange views and concentrating on problem solving and participating in activities in the learning process (MEB, 2010, p.11-12). When the "general objectives" section of the program is examined, some critical thinking skills are suggested to be developed for students such as understanding and using religious concepts correctly, distinguishing between true religious knowledge and superstitions and superstitions and being aware that different religious understandings and experiences in society are social phenomenons (MEB, 2010, p.12).

In the process of determining the learning areas of the program, it was seen that the items such as attracting students' interest, creating curiosity and enthusiasm for students and encouraging depth and breadth of learning related to critical thinking skills (MEB, 2010, p.13). When the learning-teaching processes and the role of the teacher for religious culture and ethics curriculum were examined, some features related to critical thinking skills were found such as updating information, thinking, questioning, searching, structuring information and being curious (MEB, 2010, p.14). In the Curriculum, some information related to critical thinking about the role of the teacher in terms of the implementation of the activities in the classroom was also determined such as paying attention to students' ideas and uncovering students' prior knowledge of the subject and making them aware of their own ideas.

Information about the characteristics of the activities is also determined in the curriculum such as directing students to research and critical thinking on any subject, performing activities in communication and cooperation and drawing principles from the subjects learned in the activities making inferences and talking about the importance of these principles in daily life (MEB, 2010, p.19).

When the measurement and evaluation section in the program is examined, it can be concluded that the usage of the measurement and evaluation methods that evaluate the teaching process in parallel with the objectives and objectives of the course rather than the traditional assessment 
and evaluation methods are emphasized. It is emphasized in the curriculum that students' high level skills such as interpretation, information gathering, analysis, questioning, problem solving should be measured by using different tools and methods. In addition, the program proposes a process of learning and assessment that continues in cooperation rather than competition. Open-ended questions, observation forms, posters, interviews, self-assessment forms, peer assessment forms, student product files, projects and performance tasks mentioned in the program are related to critical thinking skills.

As a result, it was found that critical thinking skills spread and constitute an important place in the parts of the program such as introduction, the vision of the program, the principles and explanations related to the implementation of the program, the basic approach, the characteristics and principles for the development of the program, the structure of the program, learning-teaching processes and the role of the teacher, the assessment and evaluation.

\section{Kaynakça / References}

Aydın, M.Ş. (2011). Açık toplumda din eğitim. Ankara: Nobel Yayınları.

Aydın, H. (2008). Sokrates' in felsefesi ışığında Sokratik yönteme analitik bir yaklaşım. Üniversite ve Toplum Bilim, Eğitim ve Düşünce Dergisi, $8(2), 1-6$.

Bonwell, C. C., ve Eison, J. A. (1991). Active learning: Creating excitement in the classroom. ASHE-ERIC Higher Education Report ,Report No:1. Washington, DC: George Washington University.

Chance, P. (1986). Thinking in the classroom. New York: Teachers College, Columbia University.

Cüceloğlu, D. (1995). İyi düşün doğru karar ver. İstanbul: Sistem Yayıncılık. Doğanay, A. ve Ünal, F. (2006). Eleştirel düşünmenin öğretimi. İçerik türlerine dayalı öğretim, içinde (s. 209-261) . Ankara: Nobel Yayın-Dağitım.

Doğru, Ç. (2018). Mezhepsel çoğulculuk bağlamında din eğitimi ve öğretimini yeniden yapılandırmak mümkün mü? Iğdır Üniversitesi İlahiyat Fakültesi Dergisi, 12, 143-169. 
Facione, N. ve Facione, P. (2010). The california critical thinking disposition inventory, insight assessment. Millbrae CA: The California Academic Press.

Facione, N. (2000). Critical thinking and clinical judgment. California Academic Press. 30/01/2019 tarihinde http://www.calpress.com/resource.html adresinden erişilmiştir.

Facione, P. (1998). Critical thinking: What it is and what it counts? California Academic Press. 21/06/2015 tarihinde http://spu.edu/depts/health-sciences/grad/documents/ctbyfacione.pdf adresinden erişilmiştir.

Facione, P. (1990). Committee on pre-college philosophy, The Delphi report, No.: ED 315 423, American Philosophical Association.

Gündoğdu, H. (2009). Eleştirel düşünme ve eleştirel düşünme öğretimine dair bazı yanılgılar. Celal Bayar Üniversitesi Sosyal Bilimler Dergisi, 7 (1), 57-74.

Güneş, F. (2007). Türkçe öğretimi ve zihinsel yapılandırma. Ankara: Nobel Yayınlar1

Gürkaynak, İ., Üstel, F. ve Gülgöz, S. (2003). Eleştirel düşünme. Eğitim Reformu Girişimi.

Halpern, D. F. (2003). Thoughts and knowledge: An introduction to critical thinking. New London: Lawrence Erlbaum Associates.

İşpiroğlu, Z. (2002). Eleştirel düşünme öğretilebilir mi? 09.10.2017 tarihinde http://www.felsefeekibi.com adresinden erişilmiştir.

Karagöz, N. (2012). 15 yöntem ve 15 planla eleştirel düşünme uygulamaları: Din kültürü ve ahlâk bilgisi dersi örneği. Adana.

Kaya, H. (1997). Üniversite öğrencilerinde eleştirel akıl yürütme gücü. Yayımlanmamış yüksek lisans tezi. İstanbul Üniversitesi Eğitim Bilimler Enstitüsü, İstanbul.

Kazanc1, O. (1989). Eğitimde eleştirici düşünme ve öğretimi. Ankara: Kazanc1 Hukuk Yayınları.

Kızılabdullah, Y. (2008). Yapılandırmacılık yaklaşımının ilköğretim din kültürü ve ahlak bilgisi dersinin amaçlarının gerçekleşmesine etkisi. Yayımlanmamış doktora tezi. Ankara Üniversitesi Sosyal Bilimler Enstitüsü, Ankara.

Klausmeier, H.J. (1958). Teaching in the secondary school. New York: Harper and Brothers Press 
Kökdemir, D. (2003). Belirsizlik durumlarında karar verme ve problem çözme. Yayımlanmamış doktora tezi. Ankara Üniversitesi Sosyal Bilimler Enstitüsü, Ankara.

Kurnaz, A. (2013). Eleştirel düşünme öğretimi etkinlikleri. Konya: Eğitim Akademisi Yayınları.

Kurfiss, J. G. (1988). Critical thinking theory research practice and possibilities. Washington, D.C: Association for the Study of Higher Education.

Lipman, M. (2003). Thinking in education. Cambridge: Cambridge University.

Mckee, J. S. (1988). Impediments to implementing critical thinking. Social Education, 52(11), 444-446.

MEB. (2010). Ilköğretim din kültürü ve ahlak bilgisi dersi öğretim programı. Ankara: Milli Eğitim Bakanlığı.

Norris, S. P. (1985). Synthesis of research on critical thinking. Educational Leadership, 42(8), 40-45.

Nosich, G. M. (2001). Learning to things through. New Jersey: Prentice Hall Osmanoğlu, C. (2012). Ortaöğretim din kültürü ve ahlak bilgisi ders kitaplarında hoşgörü ve birlikte yaşama kültürü. Erciyes Üniversitesi İlahiyat Fakültesi Dergisi, 2 (15), 55-78.

Özden, Y. (2003). Öğreneme ve öğretme. Ankara: Pegem Yayıncılık.

Özden, Y. (1998). Öğrenme ve öğretme. Ankara: Pegem Yayınları.

Pascarella, E., ve Terenzini, P. (1991). How college affects students: Findings and insights from twenty years of research. San Francisco: Jossey-Bass.

Patrick, J. J. (1986). Critical Thinking in the Social Studie, ERIC Digest, EBSHOST, ERIC Document No: ED272432. 1986 21.09.2016 tarihinde http://ericir.syr.edu/ adresinden erişilmiştir.

Paul, R. ve L. Elder (2001). Critical thinking. Tools for taking charge of your learning and your life. Prentice Hall: Upper Saddle River, $\mathrm{Nj}$.

Paul, R., Binker, A. J. A., Jensen, K., and Kreklau, H. (1990). Critical thinking handbook: 4th-6th grades, A guide for remodelling lesson plans in language arts, social studies and science. Shania State University: Foundation for Critical Thinking.

Selçuk, M. (2000). Din öğretiminin kuramsal temelleri. Din Öğretiminde Yeni Yaklaşımlar, 11-20.

Selçuk, M. (1998). Din öğretimi özgürleştiren bir süreç olabilir mi? Din Öğretiminde Yeni Yaklaşımlar, 1(1), 207-224. 
Sönmez, V. (2008). Program geliştirmede öğretmen el kitabı. Ankara: Anı Yayincilik.

Şahinel, S. (2002). Eleştirel düşünme. Ankara: Pegem Yayıncılık.

Tang, C. (1998). Effects of collaborative learning on the quality of assignments. In (B. Dart ve G. Boulton-Lewis Eds.), Teaching and Learning in Higher Education (p. 102-123). Melbourne, Australia: The Australian Council for Education Research Ltd.

Topçu, N. (2005). Felsefe. İstanbul: Dergâh Yayınları.

Yıldırım, A. Şimşek, H. (2006). Sosyal Bilimlerde Nitel Araştırma Yöntemleri. Ankara: Seçkin Yayıncılık.

Tosun, C. (2003). Din öğretiminde yeni yöntem arayışları uluslar arası sempozyum bildiri ve tartışmalar. Ankara: MEB.

Walters, K. S. (1984). Critical thinking in liberal education. A case of overkill. Liberal Education, 77(3), 233-249.

\section{Kaynakça Bilgisi / Citation Information}

Öncel, S. E. (2019). İlköğretim din kültürü ve ahlak bilgisi öğretim programının eleştirel düşünme becerileri açısından incelenmesi.OPUSUluslararası Toplum Araştırmaları Dergisi, 11(18), 2797-2829. DOI: 10.26466/opus. 572254 